\title{
Invasion of Imperata cylindrica (L.) Beauv. by Eupatorium Species in Northern Thailand
}

\section{J. LINDSAY FALVEY AND PRAKOB HENGMICHAI}

\section{Abstract}

The pattern of invasion of native Imperata cylindrica swards by Eupatorium in the highlands of northern Thailand was studied by the technique of comparing invasion at different sites of known history. Eupatorium ground cover decreased with increasing distance from the night camp of cattle. Variations in the curves between different villages was attributed to the number of years of sustained grazing each site had undergone. A more detailed study of one area showed a high correlation $(r=0.887)$ between mean percent Eupatorium and the number of years of grazing, but not for estimated average stocking rate at each site. The correlation coefficient between percent Eupatorium and the product of the number of years grazing and estimated average stocking rate at each site was also high $(r=0.894)$. Some agronomic data for $E$. adenophorum in one area are also presented.

The highlands of north Thailand are populated by seven main ethnic groups who practice shifting cultivation on the steep slopes. While their prime agricultural interest is in subsistence crops or cash crops, primarily opium, ruminant livestock in the form of cattle, buffalo, and goats are also raised. Of these, cattle are present in the greatest numbers by far, and represent a relatively high income-producing potential (Falvey 1977).

Imperata cylindrica (L.) Beauv. is distributed throughout most of the tropical world, where it is usually considered to be a weed and has therefore mainly been studied in terms of control (Iven 1975). In the highlands of northern Thailand, however, it forms the basis of the present grazing industries. Imperata often populates the abandoned swiddens of shifting cultivators and persists through its fire-evading characteristics. Fires escape from the annual preparation of new swiddens and burn large proportions of the highlands each year.

It is envisaged the Imperata pastures will remain important in the highland situation because, although productivity of cattle grazing these native pastures is low (Falvey et al. 1978), increases in productivity can be obtained through simple supplementation (Mikled 1976). Animal production figures from more tropical countries where Imperata is the main pasture are considerably higher (Magadan et al. 1976), a factor that is probably related to the relative vigor of the swards due to differences in soil fertility and other environmental conditions. A compounding problem of the lower vigor of Imperata swards in the highlands of north Thailand is the invasion by unpalatable broadleafed species of the Eupatorium genus under grazing.

Eupatorium odoratum (L.) (also known as Chromolaena odorata (L)R.M. King and H. Robinson) is widely distributed in the tropics although it is believed to be a native of the West Indies and Central America. It is a perennial, diffuse, scramb-

Authors are livestock specialists. Thai-Australian Highland Agricultural Project. Faculty of Agriculture, Chiang Mai University, Chiang Mai, Thailand.

Manuscript received June 25, 1978. ling plant with a deep taproot (Holm et al. 1977). It can grow up to heights of 3 meters under favourable environmental conditions and its invading ability is enhanced by prolific annual seed production and a profuse branching habit (Holm et al. 1977). An allelopathic effect of Eupatorium species has also been suggested (C. Parker, pers. comm.). The species cannot usually persist in a closed canopy forest situation as the plants have light requirements (Ivens 1975), although E. adenophorum may be more tolerant to shading than $E$. odoratum, at least in the seedling stage (Auld and Martin 1975). Both species prefer well-drained soils (Holm et al. 1977). In the highlands of north Thailand (latitude $17^{\circ}-24^{\circ} \mathrm{N}$ ), Gibson (1976) has noted that $E$. adenophorum is usually encountered at altitudes greater than 1,100 metres while $E$. odoratum occurs at the lower altitudes although there are exceptions to the trend.

The mechanism of invasion by Eupatorium into grazed swards of Imperata has not been defined. Casual observations indicate that invasion by Eupatorium increases with the length of time an area of Imperata has been grazed. The shifting cultivation pattern of the highland dwellers and the associated removal of villages at intervals of $10-15$ years have meant that the effects of high levels of weed invasion have been avoided. Increased population in the area and decreased land available for cultivation due to government activities such as reforestation, have significantly reduced the scope of village removal and have therefore highlighted the problem of Eupatorium invasion of Imperata pastures and, to a certain extent in cropping areas.

This paper attempts to describe some of the dynamics of Eupatorium invasion, some characteristics of the species in the environment of the highlights of north Thailand, and the probable role of the species in vegetational change.

\section{Methods}

This work was conducted during 1976-77 at various sites in the highlands of northern Thailand at altitudes ranging from 700-1,400 metres. The proportion of Eupatorium species at approximately 60 random sites at varying distances around the night camp of cattle was estimated by visual estimation of the percentage ground cover at six villages. For the purposes of this study no distinction was made between the different Eupatorium species. The villages chosen for this study had all raised cattle at numbers greater than 20 head for varying numbers of years. The number of years the villages had been located at that site, or alternatively, the number of years for which cattle had been raised were also recorded.

At $\mathrm{Pa} \mathrm{Kia}$, the research site of the Thai-Australian Highland Agricultural Project, a similar though more detailed study was conducted. Information concerning the stocking pressure a given area may have received in a particular year was available as were accurate 
Table 1. Parameters used in the analysis of Eupatorium invasion data at $\mathrm{Pa}$ Kia.

\begin{tabular}{|c|c|}
\hline Term & Explanation \\
\hline Distance from the camp. & $\begin{array}{l}\text { The estimated straight-line distance from the nigh } \\
\text { camp of cattle. }\end{array}$ \\
\hline $\begin{array}{l}\text { Potential average stock } \\
\text { numbers per year. }\end{array}$ & $\begin{array}{l}\text { The average number of stock present in } 1 \text { year that } \\
\text { could have grazed on the area in question under } \\
\text { the free range conditions. }\end{array}$ \\
\hline $\begin{array}{l}\text { Maximum number of } \\
\text { stock per year. }\end{array}$ & $\begin{array}{l}\text { The maximum number of stock present during } 1 \\
\text { year that could have grazed on the area in ques- } \\
\text { tion. }\end{array}$ \\
\hline Number of years grazing & $\begin{array}{l}\text { The number of years that cattle had been allowed } \\
\text { access to that area. }\end{array}$ \\
\hline $\begin{array}{l}\text { Estimated average stock } \\
\text { numbers per year }\end{array}$ & $\begin{array}{l}\text { The average number of stock that were present in } \\
1 \text { year adjusted by the proportion of their graz- } \\
\text { ing time estimated to be spent in that area. }\end{array}$ \\
\hline
\end{tabular}

The degree of correlation of Eupatorium ground cover in the vicinity of $\mathrm{Pa} \mathrm{Kia}$ to various parameters is presented in Table 2. Correlation coefficients between the percentage Eupatorium ground cover and the parameters "distance from the camp" and the "maximum number of stock" that grazed each area in 1 year were reasonably high, while the value for the correlation to the number of years grazing was the highest. Correlation coefficients between Eupatorium percentage ground cover and the products of some other parameters were high, in particular the product of "number of years grazing" and "estimated average stock numbers per year."

Figure 3 presents the data for the mean percentage of Eupatorium over various years of grazing at $\mathrm{Pa} \mathrm{Kia}$. The straight line relationship calculated from this data was $Y=-4.4+19.6$ $X$ and is also included in the graph. The data for the relationship between the percentage Eupatorium ground cover and the product of the terms "number of years grazed" and "estimated average stocking rate" are presented as Figure 4. The straight
Table 2. Correlation coefficients between various parameters and Eupatorium ground cover at $\mathbf{P a} \mathbf{K i a}$.

\begin{tabular}{lc}
\hline Parameter & $r$ \\
\hline (A) Distance from camp & 0.489 \\
(B) Potential averagc stock numbers per ycar & 0.083 \\
(C) Maximum number of stock per year & 0.591 \\
(D) Number of years of grazing & 0.887 \\
(E) Estimated average stock numbers per year & 0.293 \\
(A) $\times$ (B) & 0.384 \\
(A) $\times$ (C) & 0.346 \\
(A) $\times$ (D) & 0.000 \\
(A) $\times$ (E) & 0.173 \\
(D) $\times$ (E) & 0.894 \\
(D) $\times$ (B) & 0.781 \\
(D) $\times$ (C) & 0.761
\end{tabular}

line relationship calculated from the data was $Y=-1.6+3.2 X$.

Figure 5 presents the degree of Eupatorium invasion within an area of radius $1 \mathrm{~km}$ (excluding areas of difficult access) around seven villages, by the number of years the villages have been established or raised cattle in numbers greater than 20 head. The curve shows a general upward trend and a relationship of the form $Y=43.96+2.71 X$ was calculated.

Agronomic data about $E$. adenophorum in the vicinity of $\mathrm{Pa}$ $\mathrm{Kia}$ are presented in Table 3. Flowering appeared to be uniform

Table 3. Some agronomic details of Eupatorium adenophorum at Pa Kia.

\begin{tabular}{ll}
\hline Characteristic & Value \\
\hline Month of flowering & February \\
Month of first seed set & Mid-March \\
Average height at maturity $(\mathrm{cm})($ March) & 135 \\
Maximum height at maturity $(\mathrm{cm})(\mathrm{March})$ & 243 \\
Density in pure sward (plants per $\left.\mathrm{m}^{2}\right)$ & 5.1 \\
Mean root depth(cm) & 56.5 \\
Maximum root depth(cm) & 78.0 \\
Mean dry matter per mature plant $(\mathrm{g})$ & \\
$\quad$ Leaves and flowers(March) & 17.9 \\
$\quad$ Woody stem & 112.8 \\
\hline
\end{tabular}

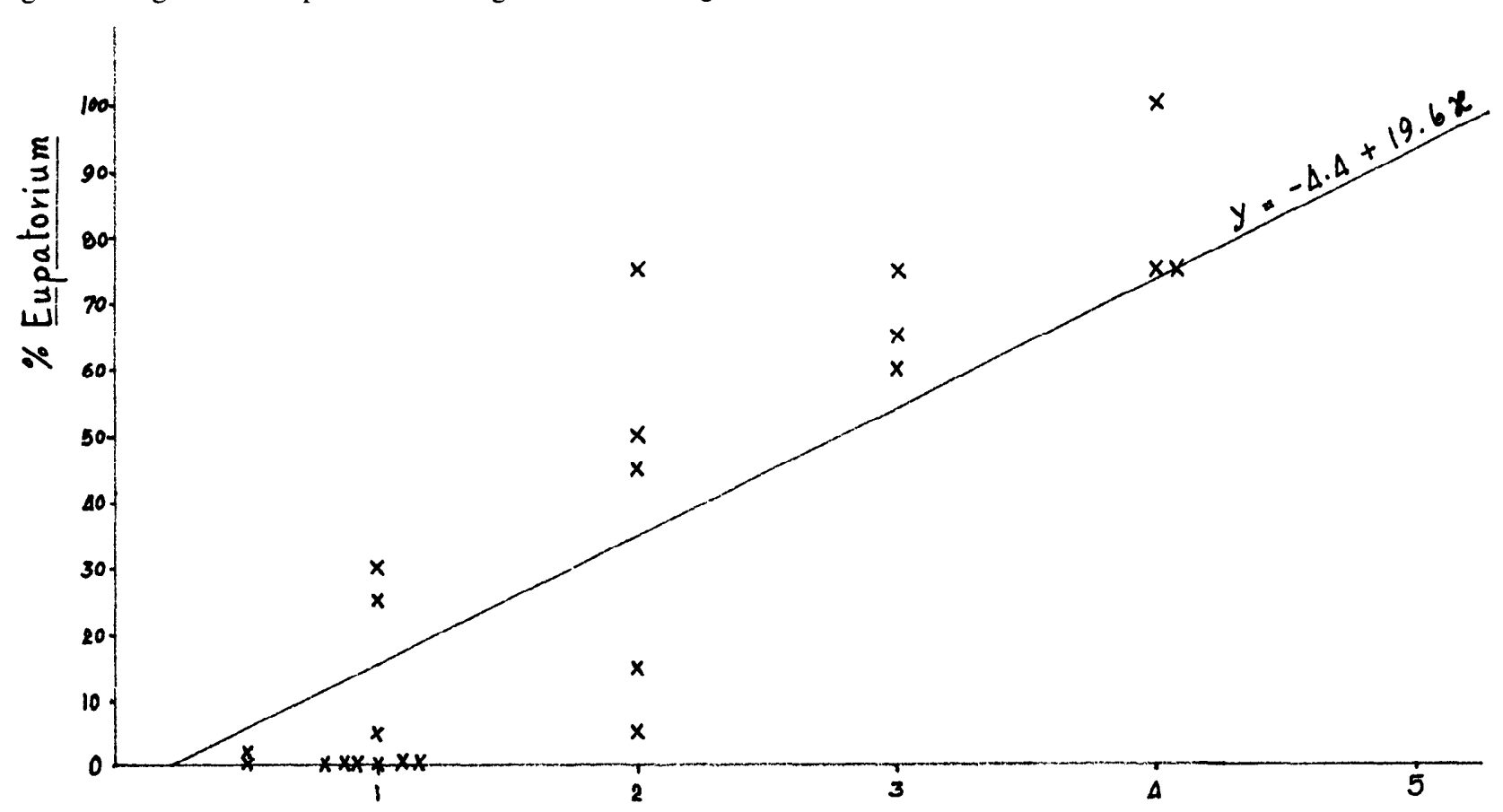

No. of years grazed

Fig. 3. Mean percent Eupatorium ground cover at various sites grazed for varying periods at Pa Kia. 


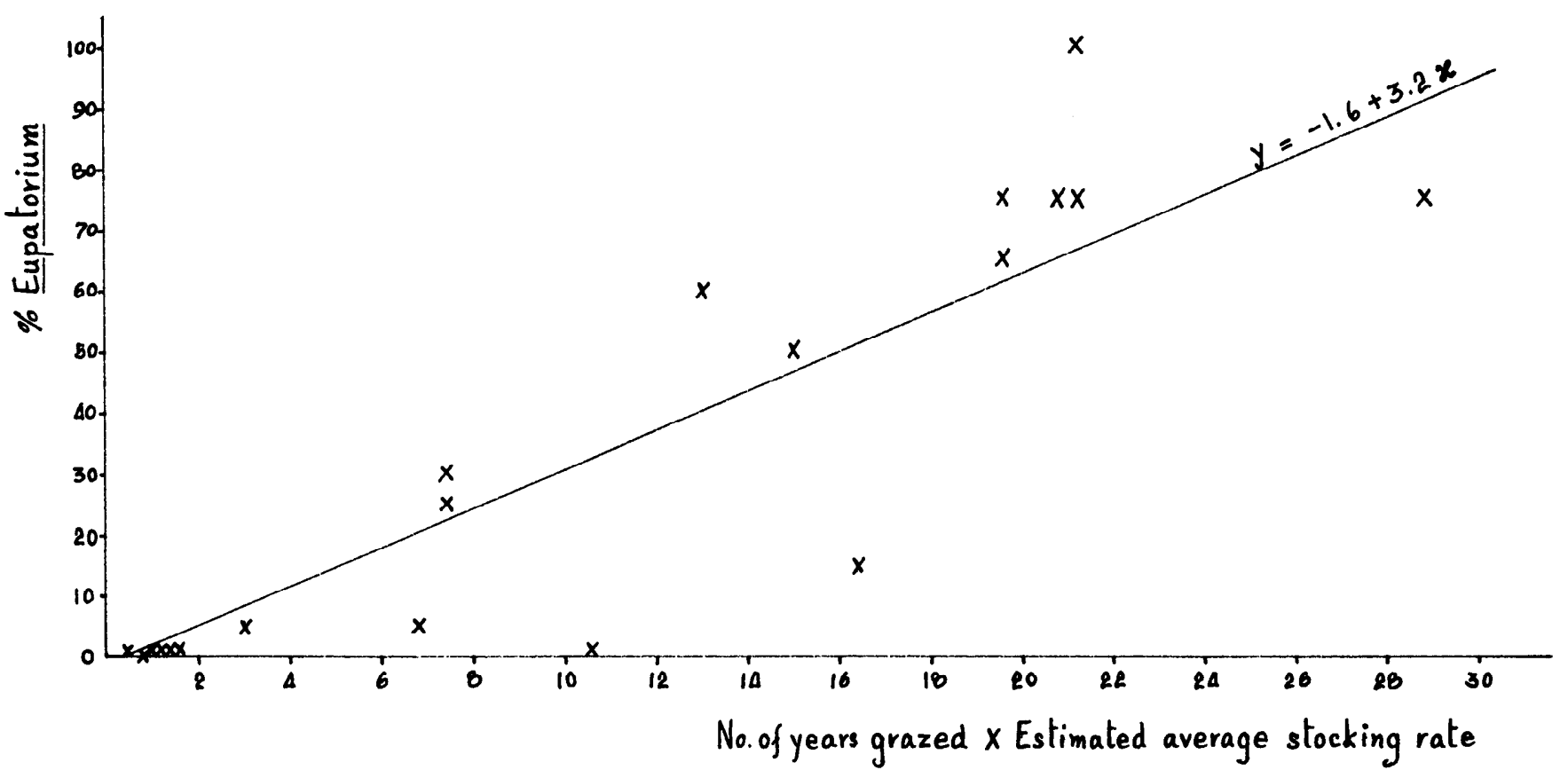

Fig. 4. Mean percent Eupatorium ground cover versus the product of number of years-estimated average stocking rates.

regardless of site, but seed maturity seemed to be related to site exposure or moisture stress. Analysis of oven-dry E. adenophorum on $8 / 10 / 77$ showed nitrogen and phosphorus contents of $2.13 \%$ and $0.25 \%$ respectively.

\section{Discussion}

Invasion of Eupatorium species into Imperata cylindrica pastures is most probably related to grazing pressure, which would be expected to decrease with increasing distance from a village where cattle usually return of an evening. The curves in
Figure 1 indicate similar trends, and the difference in curves can probably be related to the duration of the grazing pressure, as indicated by Figure 5. That this relationship is linear rather than exponential is at variance with a previous suggestion (Falvey and Hengmichai 1978). Curves showing the increase in Imperata with increasing distance from the village show a slightly different shape, indicating that weed species other than Eupatorium may be involved in some instances. However, the proportion of ground cover by Eupatorium indicates that it is the dominant weed. There did also seem to be a positive

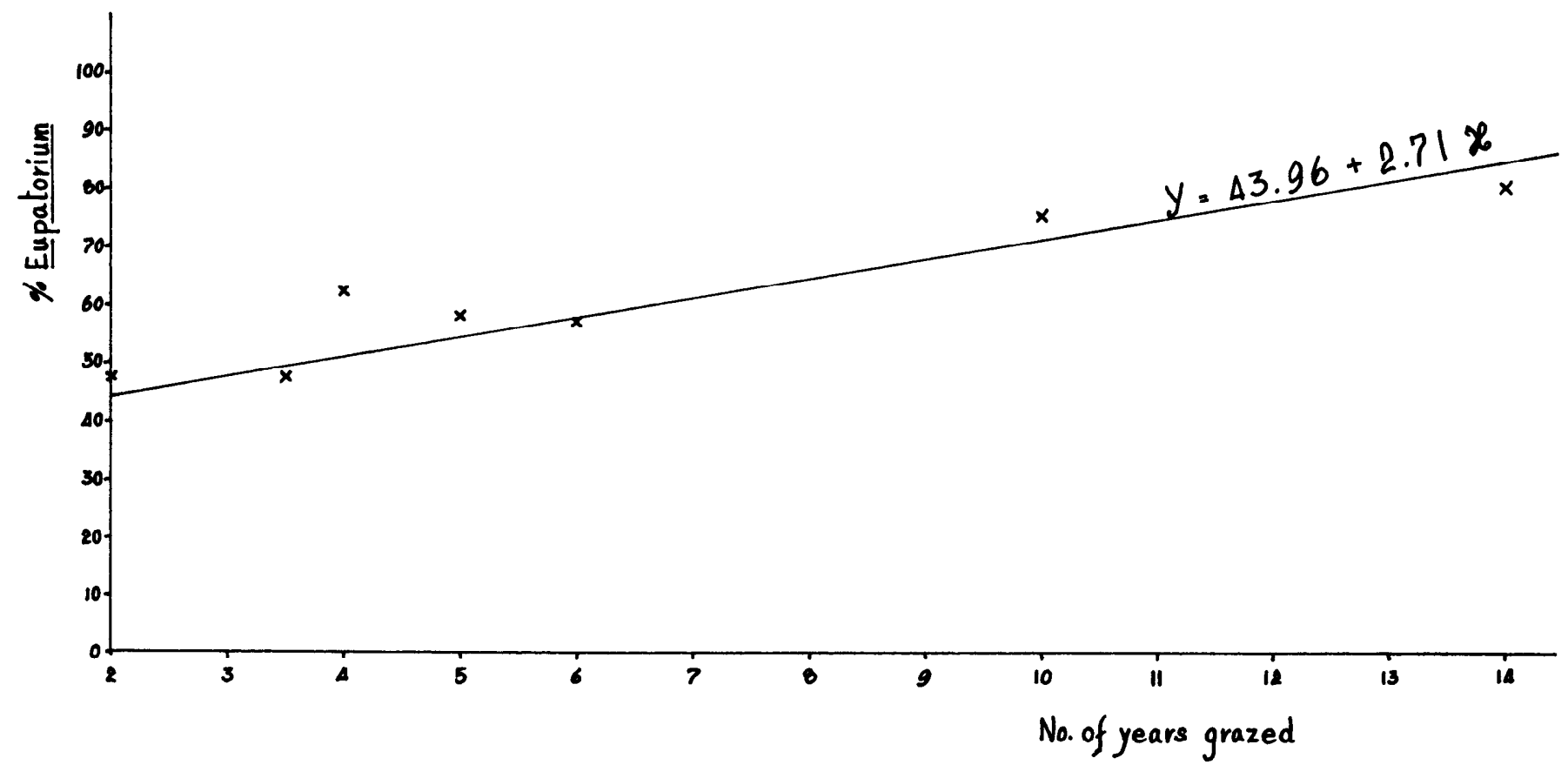

Fig. 5. Mean percent Eupatorium ground cover within an area of $/ \mathrm{km}$ from different villages where grazing of accessible sites has occurred for varying lengths of time. 
correlation (although data are not presented) with the distances cattle were forced to move out to graze with time; as the years progressed, cattle found less edible pasture in the areas closer to the village.

The simple correlation coefficients calculated from data at $\mathrm{Pa}$ $\mathrm{Kia}$ also indicate that the principal factors related to Eupatorium invasion are distance, grazing pressure, and years of sustained grazing. As distance is actually related to grazing pressure, it can possibly be eliminated in this discussion. The highly significant relationships between the product terms of "number of years grazed" and terms related to stocking pressure, in particular, the subjective term "estimated average stock numbers per year" indicate further that these factors may be the principal ones relating to Eupatorium invasion. Other variables that have been suggested (Falvey and Hengmichai 1978), such as topography, altitude, and soil type, seem to be less important with respect to invasion of Imperata.

It is possible to speculate on the role of Eupatorium in the changing environment of highlands of northern Thailand in the light of these data and other work. Imperata, which often populates deserted swidden sites and is maintained by annual fires (Iven 1975), can easily become dominated by Eupatorium species under moderate rates of grazing pressure. Until recently, removal of villages when cropping sites are less easily found has meant that animal production may not have suffered greatly. It is worthy of note that in these circumstances Eupatorium invasion was not the prime reason for village removal as it apparently has been in other countries (Holm et al. 1977). The abandoned sites, then populated by Eupatorium, which spreads over the deserted house sites and roads also, would be much less fire prone than Imperata and could thus provide an environment suitable for forest regeneration. In the more tropical environment of Indonesia, Eussen and Wirjahardja (1973) have noted that $E$. odoratum can form the first stage from Imperata dominance to secondary forest. As the forest becomes established, the shading effect of trees would lead to a decrease in vigour of the Eupatorium due to its high requirement for light (Ivens 1975), and eventually to complete or near complete disappearance of Eupatorium.
Increased land pressure in the highlands of north Thailand has rendered the previously useful Eupatorium phase a liability, because villages may not have the old option of moving. Thus Imperata pastures can be lost and animal production suffer because, although Imperata is not commonly viewed as a valuable pastures species, it is of value to the present grazing industry and will most probably remain so even with the advent of improved pastures (Gibson and Andrews 1978) and supplementary feeding (Falvey and Mikled 1978). The data provided in this paper, while not complete, do provide greater insight into the problem now being faced in the rangeland grazing industries of the highlands of north Thailand.

\section{Literature Cited}

Auld, B.A., and P.M. Martin. 1975. The autecology of Eupatorium adenophorum Spreng. in Australia. Weed Res. 15:27-31.

Eussen, J.H.H., and S. Wirjahardja. 1973. Studies on alang-alang (Imperata cylindrica (L.) Beauv.) vegetation. BIOTROP Bull. No. 6, Reg. Centre Trop. Biol., Bogor, Indonesia.

Falvey, L. 1977. Ruminants in the highlands of northern Thailand-an agrosociological study. Thai-Australian Highland Agronomy Project, Tippanetre Press, Thailand. $124 \mathrm{p}$.

Falvey, L., and P. Hengmichai. 1978. Native pastures in the highlands 2. Invasion of blady grass pastures by Eupatorium species. Third report of the Thai-Australian Highland Agricultural Project, Faculty of Agriculture, Chiang Mai University, Thailand. $107 \mathrm{p}$.

Falvey, L., and C. Mikled 1978. Dry season supplementation of cattle in the highlands of northern Thailand. Proc. Aust. Soc. Anim. Prod. 12:175.

Falvey, L., P. Hengmichai, and P. Hoare. 1978. Productivity of cattle grazing native highland pastures. Thai J. Agr. Sci (in press).

Gibson, T. 1976. First report of the Thai-Australian Highland Agronomy Project. Aust. Dev. Assistancy Agency. 134 p.

Gibson, T.A., and A.C. Andrews. 1978. Pasture agronomy research in northern Thailand highlands. Proc. Aust. Soc. Anim. Prod. 12:203.

Holm, L.G., D.L. Plucknett, J.V. Pancho, and J.P. Herberger. 1977. The World's Worst Weeds. University of Hawaii Press, Honolulu. 609 p.

Ivens, G.W. 1975. Studies on Imperata cylindrica (L.) Beauv. and Eupatorium odoratum (L.) Agr. Res. Counc., Weed Res. Org., Begbroke Hill, Oxford.

Magadan, P.B., E.Q. Javier, and J.C. Madamba. 1976. Beef production on native (Imperata cylindrica (L.) Beauv.) and Para grass (Brachiaria mutica (Forsk.) Stapf.) Proc. 12th Int. Grass Cong., Moscow: 370-378.

Mikled, C. 1977. Dry season supplementation of cattle grazing native grasslands in the north Thailand highlands. Thai Agr. Sci. 10:135-142.

\section{Increase Forage Production Plant PERMA-PEL Range \& Pasture Mixes}

Depend on Ramsey Seed - long a leader in range improvement programs - for the finest clover, subclover, and grass seed mixes. Ramsey provides 3 general mixes for varying rainfall and soil conditions ... plus special mixes for special situations. Introduce your range improvement program to Rhizo-Kote ${ }^{\circledR}$ and Nutri-Kote ${ }^{\circledR}$. The seed coatings that provide a controlled germination zone, aids seedling establishment, and offers optimum rhizobia viability for root nodulation of legumes.

\section{Write or phone for seed mix quotes (and for a free range seeding brochure)}

\section{RAMSEY SEED,INC.}

P.O. Box 352, Manteca, CA 95336 (209) 823-1721
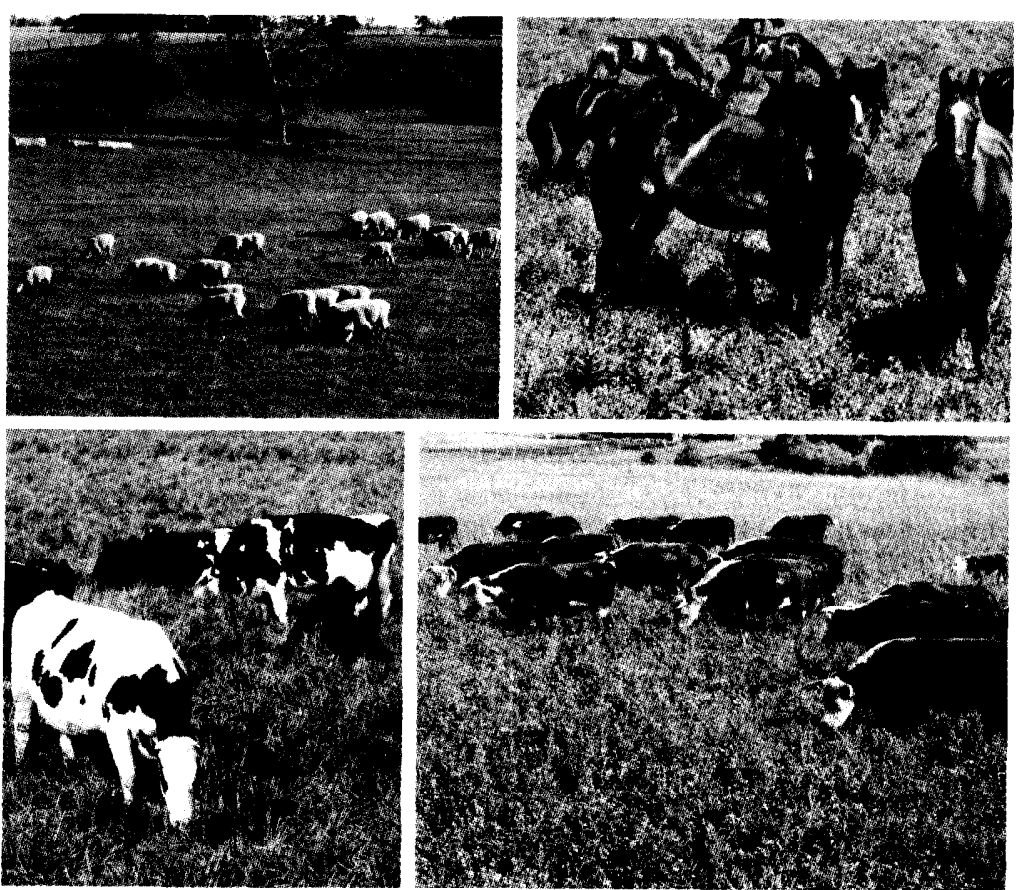